\title{
Osteochondroma in a young cat infected by feline leukemia virus
}

\author{
Matheus de Oliveira Reis ${ }^{1}$ Lauren Santos de Mello ${ }^{1}$ Kivia Lunardelli Hesse ${ }^{2}$ \\ Marina Paula Lorenzett ${ }^{1}$ Kauê Danilo Helene Lemos dos Reis ${ }^{3}$ \\ Fabrício Souza Campos ${ }^{4}$ Paulo Michel Roehe ${ }^{4}$ Saulo Petinatti Pavarini ${ }^{{ }^{*}}$
}

\footnotetext{
${ }^{1}$ Setor de Patologia Veterinária, Faculdade de Veterinária, Universidade Federal do Rio Grande do Sul (UFRGS), Avenida Bento Gonçalves, 9090, Prédio 42505, 91540-000, Porto Alegre, RS, Brasil. E-mail: saulo.pavarini@ufrgs.br. "Corresponding author.

${ }^{2}$ Médica veterinária autônoma, Porto Alegre, RS, Brasil.

${ }^{3}$ Hospital Veterinário de Pequenos Animais, Faculdade de Veterinária, Universidade Federal do Rio Grande do Sul (UFRGS), Porto Alegre, RS, Brasil.. ${ }^{4}$ Instituto de Ciências Básicas de Saúde, Universidade Federal do Rio Grande do Sul (UFRGS), Porto Alegre, RS, Brasil.
}

\begin{abstract}
Osteochondromas are primary bone tumors characterized by cartilage-covered bone projections involving single or multiple masses (osteochondromatosis). This study reports the clinical and pathological findings from a young domestic cat with osteochondroma in the humerus. During the clinical evaluation, the animal had pronounced right forelimb musculature atrophy and an increased distal humeral volume. Histopathological examination of the neoplasm revealed a proliferative lesion characterized mostly by endochondral ossification and peripheral foci of proliferating cartilage tissue. Further testing using immunohistochemical staining and polymerase chain reaction revealed the presence of feline leukemia virus antigens in the hematopoietic cells of the bone marrow and FeLV proviral DNA in the peripheral blood lymphocytes. Clinical and pathological findings are consistent with osteochondroma. This neoplasm occurred in an eight-month-old feline with humeral enlargement that had been present since two months old.
\end{abstract}

Key words: FeLV, bone cancer, osteochondromatosis.

Ostecondroma em um felino jovem infectado pelo vírus da leucemia felina

RESUMO: O osteocondroma é um tumor ósseo primário que se caracteriza por apresentar uma projeção óssea recoberta por cartilagem que pode ser formado por uma única ou por múltiplas massas (osteocondromatose). O objetivo deste trabalho é descrever os achados clínicos e patológicos de um felino jovem com osteocondroma no úmero. Na avaliação clínica, o felino apresentava atrofia acentuada da musculatura do membro torácico direito além de um aumento de volume em região distal do úmero. No exame histopatológico, observou-se uma lesão proliferativa composta em sua maior parte por ossificação endocondral com focos periféricos de tecido cartilaginoso proliferado. Testes de imuno-histoquímica e reação em cadeia da polimerase revelaram a presença de antígenos de FeLV em células da linhagem hematopoiética da medula óssea e DNA proviral em linfócitos do sangue periférico, respectivamente. Os achados clínicos e patológicos foram consistentes com um osteocondroma em um felino jovem, com oito meses de idade, com lesão em úmero desde os dois meses de idade.

Palavras-chave: FeLV, neoplasia óssea, osteocondromatose.

\section{INTRODUCTION}

Primary bone neoplasms in domestic cats are rare and only represent $4.9 \%$ of all tumors diagnosed in this species (ROSA \& KIRBERGER, 2012). One type of neoplasm is an osteochondroma, which is a benign primary bone tumor that originates from the bone surface to form a projection covered by cartilage (THOMPSON \& POOL, 2002). This tumor can be formed by one or more masses; in the latter case, it is referred to an osteochondromatosis or multiple cartilaginous exostoses (ROSA \& KIRBERGER, 2012). In cats, osteochondromas have been linked to feline leukemia virus (FeLV) infections (POOL \& CARRIG, 1972; THOMPSON
\& POOL, 2002; ROSA \& KIRBERGER, 2012). In dogs, osteochondroma has a hereditary cause (WEISBRODE, 2009), and may develop just after birth with dogs growth, while they can stabilize when the bone reaches maturity (DOIGE, 1987). However, in cats, the neoplasm often occurs in adulthood (WEISBRODE, 2009) and shows continued growth (ROSA \& KIRBERGER, 2012). The age of cats with this type of tumor usually ranges from 16 months to eight years, and it is more frequently reported in cats from two to four years old (THOMPSON \& POOL, 2002). The objective of this study was to describe the clinical and pathological findings of an osteochondroma in a cat that was younger than animals described in previous studies. 
A feline, male, mixed breed with approximately eight months old was referred for clinical examination presenting a swelling in the humeral region of its right forelimb (RTM). The cat was rescued from the street at about two months of age, and from that period on did not use the affected limb for support. A clinical evaluation of the cat showed marked muscles atrophy of the RTM and an increased volume of the distal region of the humerus. Radiology revealed a radiopaque lesion in the distal region of the upper arm extending to the diaphysis. Amputation of the RTM was elected. During the consultation, $3 \mathrm{~mL}$ of blood was collected in a tube with EDTA for polymerase chain reaction (PCR) testing. After surgery, the severed limb was fixed in a $10 \%$ formaldehyde solution and sent for histopathological evaluation. After 24 hours, the sample was trimmed and decalcified in $8 \%$ nitric acid, then dehydrated in increasing concentrations of ethanol, cleared in xylene and embedded in paraffin. The sample was cut into $3-\mu \mathrm{m}$ slices and stained with hematoxylin and eosin (HE).

Gross examination of the excised tumor revealed an irregular surface mass in the distal region of the right humerus that extended from the epiphysis to the initial third of the diaphysis and measured $5 \mathrm{~cm} \times 3 \mathrm{~cm} \times 2.5 \mathrm{~cm}$ (Figure 1A). A cut section showed that the mass was composed of a hard tissue, with mineralized areas that had a white and bony appearance, covered with a whitish softer material (Figure 1B). Microscopically, a proliferative lesion characterized mostly by endochondral ossification along with peripheral foci (external) of the proliferated cartilaginous tissue was observed (Figure 1C). Chondrocytes were intermixed throughout the tumor and had a bluish extracellular matrix containing hyaline cartilage, and they occasionally showed eosinophilic staining, necrosis and mineralization (Figure 1D).

Fragments of bone tissue were subjected to immunohistochemistry to detect FeLV antigens using a streptavidin-biotin conjugated alkaline phosphatase immunostaining kit (LSAB+ SystemAP kit, Dako ${ }^{\circledR}$, Carpinteria, CA). Antigen retrieval was performed using wet heat for 40 minutes at $96^{\circ} \mathrm{C}$ in Tris EDTA (pH 9.0). Monoclonal antiFeLV (Serotec ${ }^{\circledR}$ ) was diluted in phosphate-buffered saline (PBS) as previously described (1:500 and $1: 100)$ and incubated overnight at $4^{\circ} \mathrm{C}$. Reaction was revealed with permanent red $\left(\mathrm{DAKO}^{\circledR}\right)$ and counter stained with Harris hematoxylin $\left(\mathrm{DAKO}^{\circledR}\right)$. In both tests positive and negative controls that had been previously tested were inserted (ROLIM et al., 2016).
FeLV antigens were immunohistochemically detected in the hematopoietic cells of the bone marrow (Figure 1D, detail); however, positive stain was not observed in tumoral cells.

Total DNA was extracted from blood to detect proviral DNA. The extraction was performed on $400 \mu \mathrm{L}$ of whole blood mixed with $600 \mu \mathrm{L}$ of lysis solution $(500 \mu \mathrm{L}$ MET $2 \mathrm{x}, 100 \mu \mathrm{l} 10 \% \mathrm{SDS}$, $10 \mu \mathrm{L}$ proteinase $\mathrm{K}$ ) and incubated for 1 hour at $56^{\circ} \mathrm{C}$. Subsequently, the extraction was centrifuged at $13,000 \times g$ for five minutes. The supernatant $(500 \mu \mathrm{L})$ was incubated with $400 \mu \mathrm{L}$ of phenol and $300 \mathrm{mM} \mathrm{NaCl}$ under stirring for 30 minutes at room temperature. After centrifuging at $13,000 \mathrm{x}$ $g$ for 20 minutes, the aqueous phase was collected and incubated with $900 \mu \mathrm{L}$ of cold ethanol $\left(-20^{\circ} \mathrm{C}\right)$. Later, the sample was centrifuged at $13,000 \times \mathrm{g}$ for 20 minutes, and the supernatant was discarded. The pellet was dissolved in $50 \mu \mathrm{L}$ TE-buffer and incubated with $5 \mu \mathrm{L}$ of RNase for 15 minutes at $37^{\circ} \mathrm{C}$. The PCR was used to detect conserved regions of gag genes from proviral FeLV DNA using specific primers, as described by CASTRO et al. (2014). Proviral FeLV DNA was detected in blood sample of the cat.

The gross and microscopic findings were consistent with osteochondroma, as previously reported by other authors (POOL \& CARRIG, 1972; DOIGE, 1987; PINK \& KIRBERGER, 2012). The cat had swelling in its limb and did not support himself during the clinical evaluation; this is an important clinical finding because it demonstrates impaired locomotion, which has been reported in other osteochondroma cases (POOL \& CARRIG, 1972).

During the gross examination, a single mass localized in the distal humeral region was reported, but other reports have shown multiple exostoses in the cranium, scapula, pelvis, humerus, radius, ulna, sternum and vertebrae bones (POOL \& CARRIG, 1972; DOIGE, 1987; NOLFF et al, 2012). Osteochondromas can present as juxtacortical to normal bone, leaving the bone surface unchanged when surgically removed and not affecting the health or appearance of the animal (POOL \& CARRIG, 1972; DOIGE, 1987), or they can present as proliferative lesions in which the medullary cavity is contiguous to the adjacent normal bone (POOL \& CARRIG, 1972). The reported case supports the latter form because the lesion extended into the medullary cavity, thus require amputation of the limb. Microscopically, there can be a malignant transformation of the neoplastic cells (DOIGE, 1987), which was not observed in this case. 


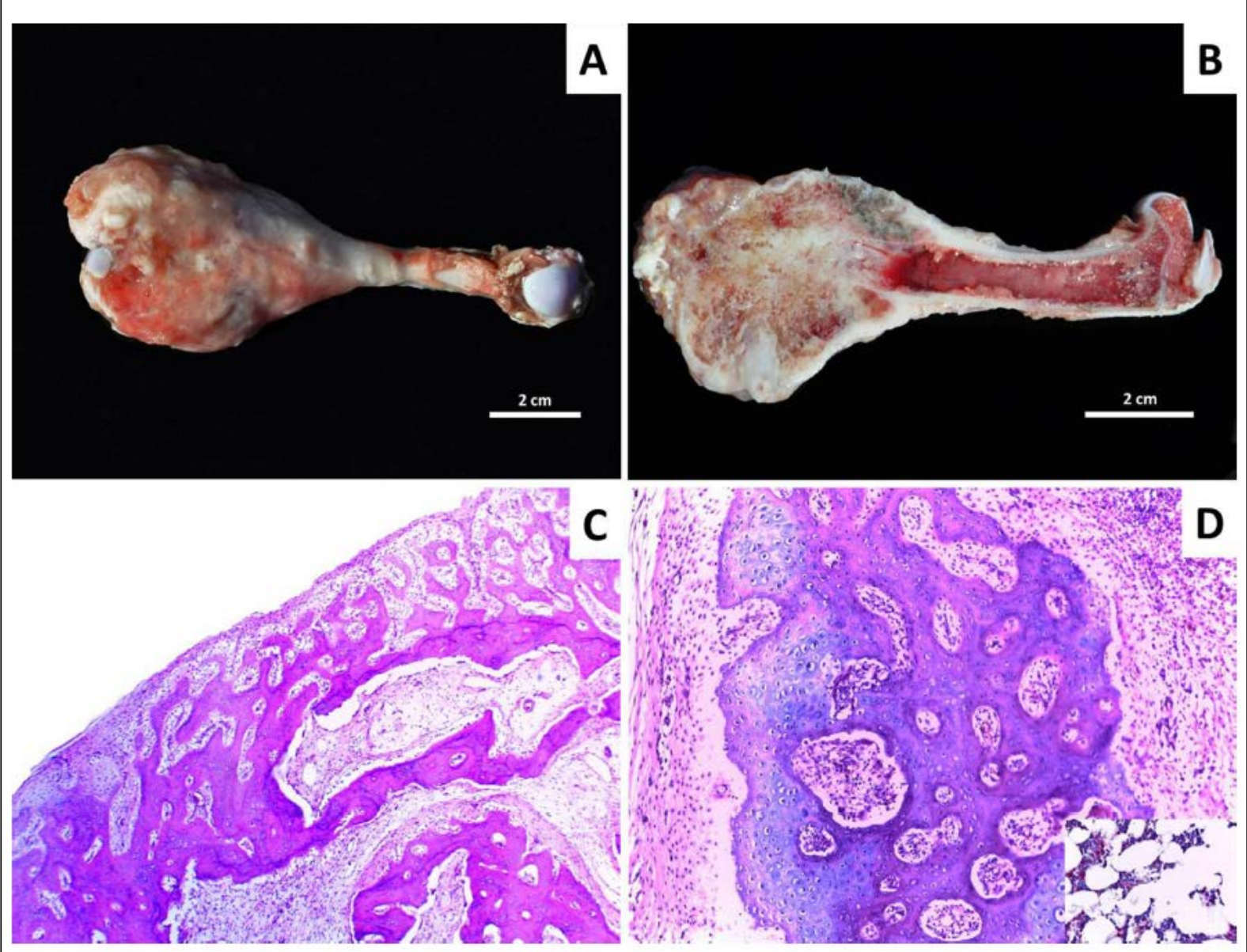

Figure 1 - Osteochondroma in the humerus of a young cat. (A) Volume increase in the distal humerus. (B) Humeral sectioning showing bone proliferation covered with whitish tissue. (C) Well-differentiated bone proliferation, HE staining, 40x. (D) Proliferated bone covered with cartilage tissue, HE staining, 200x. Detail: Bone marrow. Marked positive stain for FeLV in hematopoietic cells. IHC anti-FeLV, 400x.

The cat here presented, showed an osteochondroma on the distal region of the humerus and was diagnosed as FeLV-positive based on immunohistochemical and PCR analyses. This suggested the involvement of FeLV in the tumor induction, mainly when considered the cat's age; it was younger than described for osteochondroma in this species. Some authors suggested that FeLV may be related to the etiology of feline osteochondromas (POOL \& CARRIG, 1972; DOIGE, 1987; ROSA \& KIRBERGER, 2012), and viral particles have been observed in proliferated chondroblast membranes (POOL \& CARRIG, 1972). However, mechanisms of invasion and the pathogenesis of this disease have not been fully elucidated (POOL \& CARRIG, 1972; DOIGE, 1987; ROSA \& KIRBERGER, 2012).
According to POOL \& CARRIG (1972), the random distribution of exostoses may be related to a viral cause of the tumor. The same authors suggested the possibility of the virus being present in the lesion as the etiological agent that induces the appearance of the osteochondroma. Another hypothesis is that the virus spreads more effectively in proliferative lesions and; therefore, cannot be the cause of the neoplasia (POOL \& CARRIG 1972). There was no anti-FeLV immunostaining in the tumor cells, however, it is known that once the neoplastic initiation occurred, it may progress even after removal of the agent that induced it (KUSEWITT, 2013). Conversely, the confirmation of the cat infection by FeLV does not assert that the osteochondroma has been induced by the virus, requiring further studies to confirm this hypothesis. 
These clinical and pathological findings are similar to descriptions by other authors, which contributed to our diagnosis of an osteochondroma. In this case, the neoplasm occurred in an eightmonth-old feline with humeral enlargement that had been present since two months old, which is younger than other similar cases that have been reported.

\section{REFERENCES}

CASTRO F.L. et al. Analysis of single-nucleotide polymorphisms in the POBEC3H gene of domestic cats (Felis catus) and their association with the susceptibility to feline immunodeficiency virus and feline leukemia virus infections. Infection, Genetics and Evolution. v.27. p.389-394. 2014. Available from: <http:// www.sciencedirect.com/science/article/pii/S1567134814003128>. Accessed: Nov. 1, 2014.

DOIGE,C.E. Multiple osteochondromas with evidence of malignant transformation in a cat. Veterinary Pathology, v.24, p.457-459. 1987. Available from: $<$ http://vet.sagepub.com/content/24/5/457>. Accessed: Nov. 8, 2014. doi: 10.1177/030098588702400515.

KUSEWITT, D.F. Neoplasia e biologia tumoral. In: ZACHARY, J.F. MCGAVIN, Bases da patologia em veterinária.5.ed. Rio de Janeiro: Elsevier, 2013. p.289-321.
NOLFF, M.C. et al. Feline osteochondromatosis in a FELVnegative European shorthair cat. Tierärztliche Praxis Kleintiere, v.42, p.55-59. 2014. Available from: <http://www.tieraerztlichepraxis.de>. Accessed: Nov. 20, 2014. IP: 143.54.241.58.

POOL, R.R.; CARRIG, C.B. Multiple cartilaginous exostoses in a cat. Veterinary Pathology, v.9, p.350-359, 1972. Available from: <http://vet.sagepub.com/content/9/5/350>. Accessed: Nov. 8, 2014. doi: $10.1177 / 030098587200900505$.

ROLIM, V.M. et al. Clinical, pathological, immunohistochemical and molecular characterization of feline chronic gingivostomatitis. Journal of Feline Medicine and Surgery, Ahead of print 2016. Available from: <http://jfm.sagepub.com/content/early/2016/02/0 5/1098612X16628578.full.pdf+html>. Accessed: Apr. 26, 2016. doi: $10.1177 / 1098612$ X16628578.

ROSA, C.; KIRBERGER, R.M. Extraskeletal osteochondroma on a cat's elbow. Journal of the South African Veterinary Association, v.83, n.1, p.1-4, 2012. Available from: $<$ http://www.jsava.co.za/index. php/jsava/article/viewFile/104/918>. Accessed: Nov. 25, 2014.

THOMPSON, K.G.; POOL, R.R. Tumors of bones. In: MEUTEN, D.J. Tumors in domestic animals. Ames: Iowa State, 2002. Cap.5, p.245-317.

WEISBRODE, S.E. Ossos e articulações. In: McGAVIN, M.D.; ZACHARY, J.F. Bases da patologia em veterinária. Rio de Janeiro: Elsevier, 2009. Cap.16, p.1041-1106. 